\title{
The dynamics of soybean seed production and cost structure at farmer level in Konawe and South Konawe Districts, Southeast Sulawesi Province
}

\author{
Siti Mutmaidah*, and Dian Adi Anggraeni Elisabeth \\ Indonesian Legumes and Tuber Crops Research Institute (ILETRI), Jalan Raya Kendalpayak Km 8 \\ Malang, East Java 65101, Indonesia
}

\begin{abstract}
Research aimed to obtain information on the dynamics of soybean seedling in Southeast Sulawesi Province and its income structure at farmer level. The research was conducted in Landano Sub-district, Konawe Selatan Regency and Pondidaha Sub-district, Konawe Regency which were selected purposively as soybean centers in Southeast Sulawesi. Data collected through interview, observation and documentation studies were analyzed descriptively using cross tabulation, including financial feasibility of soybean seed production. In 2010-2018 there were fluctuations in the planting area and soybean harvest. The highest production and productivity occurred in 2016, experiencing an increase of $21 \%$ even though the planting area decreased by $22 \%$ from 2015. However in 2016, soybean seed production in Southeast Sulawesi was only able to meet $73.5 \%$ of the need for seeds in the province. Anjasmoro is a preferable variety by farmers because its large seed is suitable for raw material of tofu and tempeh industry. In addition, other characteristics of Anjasmoro interested in are its resistant to falling, leaf rust disease, and pod breaking. Analysis of soybean seed production at breeder farmer level showed that from selling $1,000 \mathrm{~kg}$ of seeds, the net profit obtained was IDR 262,100 with an $\mathrm{R} / \mathrm{C}$ ratio $>1$.
\end{abstract}

\section{Introduction}

In the last five years the average amount of domestic soybean production was about 982.47 tons of dry beans. This production just fulfill $43 \%$ the needs of national soybean. The gap rate between national soybean demand and supply needs approriate efforts from the Government of Indonesia through the Ministry of Agriculture. Last 2018, the Indonesian Ministry of Agriculture proclaimed that year as the year of soybean production in order to succed the program in increasing domestic soybean production towards self-sufficiency [1]. One of the efforts has been, is, and continues conducted by the Government of Indonesia to strive the expanding of soybean planting area, not only by utilizing the idle land but also planting soybean in the paddy fields after the paddy harvest period. These efforts are carried

* Corresponding author: sitiasdianto@yahoo.co.id 
out throughout provinces in Indonesia, particularly outside Java Island, including Southeast Sulawesi Province as one of the soybean production centers in Sulawesi Island.

Data of the 2004-2018 showed that in 2004 total soybean production in Southeast Sulawesi Province was 2.381 tons and the value increased about four times in 2018 become 9.853 tons. The average area for soybean planting during 2004-2018 was 4.644 ha with the average production was 5.759 tons and the average productivity was 1.182 tons/ha [1,2] added that the expanding soybean planting area in dryland and rainfed rice field of Southeast Sulawesi Province just contributed to $0.46 \%$ of national soybean production. With the average growth rate of soybean productivity was $2 \%$ per year, the soybean productivity of Southeast Sulawesi Province was still lower than the national soybean productivity which is of 1.42 tons/ha.

Some factors affecting to the low soybean productivity in farmer level recorded from some studies were the low use of certified and high-quality soybean seeds in farmer level [3]; the difficulty in accessing certified soybean seeds [4]; and the lack of local seed producers or seed bredeers development $[5,6]$ mentioned that seeds has an important role as delivery mechanism which will promote and deliver the advantage of agricultural technology to the stakeholders particularly farmers. However, [7] recorded that the use of certified soybean seeds from the new improved variety in Southeast Sulawesi Province was still 28\% from the total soybean planting area.

The only effort for ensuring the distribution of certified and good quality soybean seeds is by developing local soybean seed breeders at the soybean production center [8]. Crop seed development strategy pursued through five approaches, namely: (a) strengthening of seed systems; (b) seed agribusiness development; (c) strengthening of seedling institutions; (d) market potential development; and (d) partnership development [1]. The success of efforts to increase domestic soybean production through area expansion planting/ harvest and improved productivity levels is determined by many factors, one of wich is the availability of quality seed that meet a number of criteria of accuracy, including: right variety, right quantity, right quality, on time, and right price. Regarding to the important position of seed breeders for seed availability, the profitability of soybean seed production business in local seed breeder level should be improved. By increasing the soybean productivity in seed breeder level which then increase its profitability will affect to the feasibility of soybean in farming level and its derivative agrobusiness [9]. The research objective was to obtain information about the dynamics of seeds in Southeast Sulawesi Province and the income structure of the soybean seed production business at the farmer level.

\section{Materials and methods}

The research was conducted in Konawe Selatan and Konawe Districts, Southeast Sulawesi Province, in August 2016. The locations were chosen purposively on the basis of considerations that in 2015, Konawe Selatan district is the largest soybean production center in Southeast Sulawesi Province with a harvest area of 2,439 ha, production 4,526 tons, and productivity $1.856 \mathrm{t} / \mathrm{ha}$; while Konawe District is in third place with a harvest area of 892 ha, production of 1,719 tonnes, and productivity of $1.927 \mathrm{t} / \mathrm{ha}$ [10]. Data collected through interviews, observation and documentation study.

The data were analyzed descriptively using cross tabulation and analysis of the financial viability of soybean seed production. The analysis used was to determine the income and income of soybean seed farming. using a formula [11]: $T C=F C+V C$. In order to know the income of soybean farming using the formula: $\mathrm{TR}=\mathrm{P} \times \mathrm{Q}, \Pi=\mathrm{TR}-\mathrm{TC}$ where $\pi=$ soybean farming income (IDR) 


\section{Results and discussion}

The fluctuations in the planting and harvesting area of soybeans data for 2010-2018 shows, the highest production and productivity occurred in 2016, experiencing an increase of $21 \%$ even though the planting area decreased by $22 \%$ from 2015 . The soybean productivity still has a great opportunity to be increased, because now it has available soybean cultivation technology capable of producing 1.75-3.40 t / ha of dry beans. In 2016, Southeast Sulawesi new soybean seed meets 73, $5 \%$ provincial seed needs (Table 2), and seed production still decreasead until 2018 (Table 1). The Indonesian agriculture Statistics data in 2015 say that the increase in soybean production by $9 \%$ from the previous year, but the production of soybean seeds continue to decline. This is indicates that the soybean seed production business in Southeast Sulawesi is very likely to be developed [2]. The phenomenon in 2015, El Nino, had an impact on the productivity of soybean crops in Southeast Sulawesi, including in South Konawe District where there was an increase land of puso from 51 ha in 2014 to 197 ha in 2015. The dominant cause of crop failure is drought [12]. The effects of drought still felt by farmers until the year 2016. As a result, the eighth breeder of seed with an area of 157 ha of crop failure (puso) and the biggest is in South Konawe area of 95 ha (61\%) (Table 2 and Table 3).

The areas of seed breeders that continue to exist in Southeast Sulawesi are those that already have links or access to market partnerships with large seed entrepreneurs such as PT. Pertani and PT. Sang Hyang Seri. The marketing communication system formed between farmer-level seed breeders and large seed entrepreneurs is as follows: to ensure demand for seeds in terms of quantity, price and time of demand, farmer-level seed breeders coordinate with large seed entrepreneurs or program implementers, in this case the agency. - government agencies, because most of the supply of certified superior soybean seeds (quality seeds) is aimed at meeting requests from government agencies related to programs implemented such as direct assistance for superior seeds (BLBU), integrated crop management field schools (SLPTT) or expansion of planting areas (PAT), and only a small proportion of the demand for the commercial market in this case among soybean farmers. This coordination forms a self-market guarantee for the farmer-level seed breeders involved to meet the demands of government programs so that their seed production process does not suffer losses.

Table 1. Development of harvested area, production and productivity of soybean in Southeast Sulawesi Province, 2013-2018

\begin{tabular}{|c|c|c|c|c|c|}
\hline Year & Planted & $\begin{array}{c}\text { Harvest area } \\
\text { (ha) }\end{array}$ & $\begin{array}{l}\text { Production } \\
\text { (ton) }\end{array}$ & $\begin{array}{l}\text { Productivity } \\
{\text { (quintal } \text { ha }^{-1} \text { ) }}^{\text {Pro }}\end{array}$ & $\begin{array}{c}\text { Spread Seed } \\
\text { Production(ton) }\end{array}$ \\
\hline 2010 & & 2,661 & 3,203 & 1,204 & 28.00 \\
\hline 2011 & & 5,814 & 6,113 & 1,051 & 123.40 \\
\hline 2012 & & 3,870 & 3,710 & 0.959 & 19.60 \\
\hline 2013 & 6,062 & 3,735 & 3,595 & 9.63 & 0 \\
\hline 2014 & 9,602 & 5,079 & 5,691 & 11.20 & 3.00 \\
\hline 2015 & 10,405 & 7,888 & 12,799 & 16.23 & 240.40 \\
\hline 2016 & 8,084 & 8,289 & 16,136 & 19.47 & 22.10 \\
\hline 2017 & 6,651 & 2,425 & 4,055 & 16.72 & - \\
\hline 2018 & 2,801 & 4,413 & 8,007 & 18.15 & 93.00 \\
\hline Average & $7,267.5$ & $4,908.2$ & $7,034.3$ & 10.5 & 63.7 \\
\hline
\end{tabular}

Source: Indonesian Agricultural Statistics, The Ministry of Agriculture of the Republic of Indonesia (2015 and 2019) $[13,14,15]$

With the development of seed production at the farm level is expected to need quality seed can be easily obtained by farmers in sufficient quantities and on time, in a larger scale, seed 
production is not only used to meet its own needs, but can also be marketed to meet the needs of the region other. Certified soybean seed breeding business can provide benefits including meeting seed needs during the growing season, as well as increasing production and income [16]. Complete data on soybean seed breeders in Southeast Sulawesi with their production in 2016 is presented in Table 2.

Table 2. The need for soybean seeds in Southeast Sulawesi Province, 2016

\begin{tabular}{|c|c|c|c|c|c|c|c|}
\hline & \multirow{2}{*}{ Districts } & \multirow{2}{*}{$\begin{array}{c}\text { Extensive } \\
\text { planting } \\
\text { (Ha) }\end{array}$} & \multirow{2}{*}{$\begin{array}{c}\text { Need } \\
\text { for seed } \\
\text { (ton) }\end{array}$} & $\begin{array}{c}\text { Produc } \\
\text { tion } \\
\text { (ton) }\end{array}$ & $\begin{array}{c}\text { \% } \\
\text { Fulfill } \\
\text { ment } \\
\text { Need }\end{array}$ & \multicolumn{2}{|c|}{$\begin{array}{c}\text { Availability seed appropriate } \\
\text { varieties (x 000 ton) }\end{array}$} \\
\hline Buton & 78.7 & 3,148 & - & 0.0 & & Anj & Arg \\
\hline Muna & 576.5 & 23,060 & 77,500 & 336.1 & - & 14,4 & 21.4 \\
\hline Konawe & $1,348.7$ & 53,948 & 12,500 & 23.2 & 20. & 15 & \\
\hline Kolaka & 2,365 & 94,604 & 59,000 & 62.4 & 29,5 & 4. & \\
\hline $\begin{array}{c}\text { South } \\
\text { Konawe }\end{array}$ & $2,021.3$ & 80,852 & 37,140 & 45.9 & 50 & 0.5 & \\
\hline Bombana & 832.7 & 33,308 & 20,000 & 60.0 & 12,5 & & \\
\hline $\begin{array}{c}\text { North } \\
\text { Buton }\end{array}$ & 402.3 & 16,092 & 13,500 & 83.9 & 14. & 80. & \\
\hline $\begin{array}{c}\text { North } \\
\text { Konawe }\end{array}$ & 345.0 & 13,800 & - & 0.0 & & & \\
\hline $\begin{array}{c}\text { East } \\
\text { Kolaka }\end{array}$ & 73.5 & 2,940 & & 0.0 & & & \\
\hline $\begin{array}{c}\text { Konawe } \\
\text { Islands }\end{array}$ & 80.3 & 3,212 & - & 0.0 & & & \\
\hline $\begin{array}{c}\text { West } \\
\text { Muna }\end{array}$ & 429 & 17,160 & 35,000 & 204.0 & & & \\
\hline $\begin{array}{c}\text { South } \\
\text { Buton }\end{array}$ & 5.0 & 200 & - & 0.0 & & & \\
\hline $\begin{array}{c}\text { Kendari } \\
\text { City }\end{array}$ & 95.9 & 3,836 & - & 0.0 & & & \\
\hline Bau bau & 7.0 & 280 & - & 0.0 & & & \\
\hline Total & 8,084 & 346,440 & 254,640 & 73.5 & & & \\
\hline
\end{tabular}

Source: BPSB and Southeast Sulawesi Provincial Agriculture Office [18], [19]

Ket: Anj = Anjasmoro, $W=$ Wilis, $S=$ Sinabung, $G=$ Grabogon Agr $=$ Agromulyo

However, further information on the BPSB Southeast Sulawesi province said that the number of producers or seed at the farm level in Southeast Sulawesi in 2016 is not growing during the 2015-2018, it is also characterized by a decrease in the number of seedlings for distribution of soybean production in Southeast Sulawesi (Table 2). The causing factors the underdevelopment of seed breeding include: (i) there is no market guarantee for the seeds produced by breeders at the farmer level, (ii) the lack of understanding and skills of farmers in producing quality seeds, and (iii) low awareness / understanding of farmers in use of superior quality seeds (iv) natural factors where the rainy weather is very low. This is consistent with that proposed by [17] that the critical factor in the growth of communitybased seed breeders are farmers' skills, availability of seed sources, time of planting, and marketing. 
Table 3 . Cultivator and production of Anjasmoro variety soybean seeds in Southeast Sulawesi Province, 2016

\begin{tabular}{|c|c|c|c|c|c|c|c|}
\hline \multirow{2}{*}{ Districts } & \multirow{2}{*}{$\begin{array}{c}\text { Number } \\
\text { of } \\
\text { Cultiva } \\
\text { tors }\end{array}$} & \multirow{2}{*}{$\begin{array}{c}\text { Seed } \\
\text { class }\end{array}$} & Tested & Graduated & Not pass & Checked & Graduated \\
\cline { 5 - 8 } & 4 & BR 1 & 133,500 & 77,500 & 32,000 & 124 & 124 \\
\hline Muna & 2 & $\begin{array}{c}\text { BR 2 } \\
\text { BR 1 }\end{array}$ & 17,000 & 12,500 & 4,500 & 91 & 26 \\
\hline Konawe & 8 & BR 1 & 67,000 & 59,000 & 8,000 & 194 & 194 \\
\hline Kolaka & 6 & $\begin{array}{c}\text { BP 1, } \\
\text { BR1 }\end{array}$ & 81,140 & 37,140 & 25,000 & 420 & 220 \\
\hline $\begin{array}{c}\text { South } \\
\text { Konawe }\end{array}$ & 2 & BR1 & 30,000 & 20,000 & 10,000 & 17 & 17 \\
\hline Bombana & 1 & BR 1 & 48,000 & 13,500 & 34,500 & 55 & 55 \\
\hline $\begin{array}{c}\text { North } \\
\text { Buton }\end{array}$ & 4 & BR 3 & 60,000 & 35,000 & 25,000 & 108 & 108 \\
\hline $\begin{array}{c}\text { West } \\
\text { Muna }\end{array}$ & & 436,640 & 254,640 & 139,000 & 1,008 & 743 \\
\hline \multicolumn{2}{|c|}{ Total }
\end{tabular}

Source: BPSB Southeast Sulawesi Province [18]

\subsection{The Dynamics of seed utilization at farmers level}

How to get seeds for farmers :

\section{From the crops themselves}

a. In addition to the formal seed system, there are informal seed systems, which are systems that awakened from its own farmers to meet the needs seed independently .. In this system, farmers set aside some of the harvest of the previous growing season (save seed) for its own use or for sale at the local level. In this system generally, farmers only plant soybeans once a year. From the previous harvest, the farmers sorted the prospective seeds by selecting seeds that were pithy (not moldy, not injured by pests and shiny in color). and dried until the moisture content reaches $11 \%$. The results of the seed sorting are stored in jerry cans or tightly closed plastic / polytylene drums, sealed with wax. The number of seeds stored generally exceeds $20 \%$ of the required planting area. On average, each farmer needs seeds for a land area of 1.0 - 1.5 ha. If there is a shortage, farmers will borrow or buy from other farmers.

b. Farmers are already planting soybeans before planting on a small portion remaining land for the preparation of seeds to be used during the planting season arrives. In this system the seeds produced not through the process of monitoring, testing, and certification from BPSB..

\section{Government / project assistance}

Soybean seeds from government obtained as an government assistance through soybean development projects. Regarding this soybean seed assistance, most farmers are basically agree, because they accept it free and they believe that the soybean seed received is a good quality one for the following reasons: (i) the seed is the new improved variety, (ii) the seed produced by authorized seed breeder therefore it tend to be pure or will not mixed with other variety in one package, and (iii) the seed has good viability. However, according to the information of some farmers, sometimes the soybean seed assistance was not appropriate with their expectation. Due to the late distribution time in farmers level which is not suitable with their soybean planting season, farmers cannot use the certified and good-quality soybean seed assistance; and then sometimes farmers find that the seed 
assistance was in poor quality showed by the low seed germination because of that late distribution.

\subsection{Seed producers}

In producing soybean seeds to support the government's soybean development program (additional planting area program). Involving three parties, namely:

a. Farmer

Farmers as parties who plant soybeans in the field, have the seeds obtained from their own harvest or prepared by the government. In this case what farmers do includes: (i) planting, (ii) maintaining plants, (iii) harvesting, (iv) drying stover, (v) threshing seeds, and (vi) drying the seeds of the harvest (not final), because besides still being mixed with pod bark and broken stems / branches, the water content is still high, around 13-14\%. The farmers' crops are sold to collectors, then the collectors sell to seed producers, or sold directly to seed producers.

b. Collecting traders

Collector traders play a role in buying farmers' crops. Here, wholesaler traders choose farmers' crops that are suitable for processing into seeds, by looking at the physical appearance of the product, including the number of seeds / grains that are green (unripe) and black (rotten / moldy), and the integrity of the seeds (not attacked by caterpillars). The purchased seeds are then processed further, namely cleaning the mixture of pod bark and broken branches / stems of soybeans. This processing work is done by blowing (farmers call blower). The results of the processing are then sold to soybean breeders.

c. Breeder

The breeder buys the prospective seed from the processing of the collectors. Here the prospective seeds are further processed, namely: (i) drying to (10 - 11\% moisture content), (ii) sorting to take green seeds / granules and being attacked by pests / diseases ( done manually ), and (iii) packaging in a plastic bag.

For the system of procuring seeds from farmers' products that are directly sold to breeders, the role of the collecting traders is taken over or done by the breeders. The seeds produced by breeders are sold to large seed traders, namely PT Pertani or Sang Hyang Sri (SHS).

The causes of the low level of use of quality seeds at the farmer level are (1) limited availability of certified seeds, (2) the high price of quality seeds, and (3) farmers' lack of understanding in the use of quality seeds $[2,20]$. This condition causes farmers to end up using seeds from the previous harvest / selected consumption soybeans, from fellow farmers, or buying from markets / agricultural shops, with unclear varieties and seed quality. Farmers use of quality seeds is only when there is a seed of government assistance. Therefore, to encourage the use of quality seeds in farmers, the initial effort that can be done is to grow seed captive at the farmer level so that the supply of seed sources can be guaranteed and sustainable.

\subsection{The dominant variety that farmers prefer}

Table 2 mentions varieties grown in Southeast Sulawesi in the period 2011-2016 are: Anjasmoro, Argomulyo, Wilis, Grobogan, Sinabung and Anjasmoro dominant varieties is about 48\%. Anjasmoro variety are the dominant variety planted, the advantages of Anjasmoro variety are: (1) suitable for tofu and tempeh raw materials, (2) large seeds, (3) resistant to falling, and resistant to leaf rust disease. in addition, (4) the pods are not easily broken [21].Table 2 shows that Anjasmoro is dominantly planted in Konawe, Kolaka, 
Konawe Selatan, Bombana and Buton Utara districts, while Muna Regency has the most diverse distribution of varieties, namely Wilis, Sinabung, Grobogan and the dominant variety of Argomulyo, which is $60 \%$.

From the results of interviews with farmers, farmers are more interested in planting the Anjasmoro variety, because of its high yield, large seed size, and the pods are not easily broken so they are suitable for use as raw material for tofu and tempeh. Although there are several high yielding varieties introduced in 2016 at SL-Mandiri Benih location. namely Dega 1 and Dena 1, but they are not attractive to farmers because even though the yield is high and the size of the seeds is large, the pods break easily. Therefore, at the SL-Mandiri benih location in 2017, an area of 3.0 ha, apart from Anjasmoro as the main variety, was also introduced to the Detap 1 variety, which has the characteristics of pod shatter resistance.

\subsection{Structure of soybean seed production business income}

The farm analysis in Table 4 is: (a). The analysis of farmer seed production at the farmer level, and (b). Procurement breeder seed (in the case Landano and Sabulakoa Village, Landano Subdistrict, South Konawe). The farm analysis of seed production at the farmer level is the cost for planting, harvesting and processing the harvest. Based on the results of the analysis, the total cost of producing soybean candidates at the farm level is IDR. $5,131,500$.

The net profit of a soybean seed breeder in Southeast Sulawesi is IDR $262.1 \mathrm{~kg}^{-1}$. This is in accordance with the results of an interview with Mr. Johanes (owner of PB. Lakomea Jaya in Sabulakoa District, Konawe Selatan Regency) who stated that the net profit for soybean seed breeding is around IDR. 200 - IDR. $300 \mathrm{~kg}^{-1}$.

Efforts to increase soybean seedlings in Southeast Sulawesi

a. Assistance for SL-Mandiri Benih

The activities focused on human resources training, conducted with assistance to farmers in seed production so that farmers are able to increase their knowledge and mastery and application of seed production technology. The positive results of the SLMandiri Benih assistance can be seen from:.

- The graduation rate for planting in the field

In general, the graduation rate for the total field crop breeding in Southeast Sulawesi in 2016 was 73,7\%, while for SL-Mandiri the seed is $100 \%$. Plant failure in the field is due to poor growth due to drought, pests, and / or a mixture of other varieties.

- Rate of seed yield per unit area

Of the total captivity in Southeast Sulawesi in 2016 covering an area of 1,008. ha, the yields of seeds examined were only 436.60 tons or the productivity of prospective seeds was $433 \mathrm{~kg} \mathrm{ha}^{-1}$, while in SL-Mandiri benih were higher, namely $37 \%$ or as much as $1,167 \mathrm{~kg} \mathrm{ha}^{-1}$.

- Passing level of seed candidate certification

For the total captivity of Southeast Sulawesi, out of 436.60 tons of seed candidates submitted for certification, only 254.60 tons $(58.3 \%)$ passed. In the SL Mandiri Seed activity, out of 7.00 tons submitted, they passed 5.00 tons of certification (or as much as $71.4 \%$ ). The cause of failing the certification test is mainly due to high water content and / or low germination

\section{b. Human Resources Development}

Among others: (a). Cultivation technology training, control of crop / disease, and postharvest (processing of crops / seeds) especially in drying, (b). Submission of publications related to soybean production / cultivation technology, (c). Provision of 
new high yielding varieties of soybean Detap 1 (pod shatter resistance) as an alternative to superior varieties other than Anjasmoro.

Table 4. Analysis of soybean seed production per hectare at the farmer level and soybean breeder farms at the soybean breeder level in Southeast Sulawesi

\begin{tabular}{|c|c|c|c|}
\hline $\begin{array}{c}\text { Description of the } \\
\text { cost of producing } \\
\text { seeds at the farmer } \\
\text { level in hactare }\end{array}$ & Total (IDR) & $\begin{array}{c}\text { Description of } \\
\text { farming costs at the } \\
\text { soybean breeder level }\end{array}$ & Total (IDR) \\
\hline Input production & & Purchase price & $7,000,000$ \\
\hline Seed (40 kg) & 324,000 & $\begin{array}{c}\text { Sorting Power }(3 \\
\text { people: } 2 \text { ton day }\end{array}$ & 150,000 \\
\hline $\begin{array}{c}\text { Inorganic Fertilizer } \\
\text { (NPK 130 kg, Urea } 80 \\
\text { kg) }\end{array}$ & 443,000 & Transport force & 50,000 \\
\hline Herbicide (7 L) & 420,000 & Drying power & 100,000 \\
\hline Pesticide (4 L) & 200,000 & Label / Label & 25,000 \\
\hline Labor & & package(10 kg package & 300,000 \\
\hline Land clearing & 225,000 & Testing Costs & 23,750 \\
\hline Cultivation (tractor) & 325,000 & Certification Fee & 30,400 \\
\hline Planting & 845,000 & Shipping costs & 150,000 \\
\hline Fertilization & 130,000 & & $8,075,000$ \\
\hline Spraying & 470,000 & & $7,812,900$ \\
\hline Harvest & 700,000 & & 262,100 \\
\hline Drying & 180,000 & & \\
\hline Threshing services $8:$ & 701,500 & & $7,812,900$ \\
\hline 1 & 168,000 & & $8,075,000$ \\
\hline package and Transport & $5,131,500$ & Total Cost & 262,100 \\
\hline Total cost & $6,313,500$ & Revenue (950 kg x & IDR. 8500$)$ \\
\hline Revenue (1,035 kg $x$ & $1,182,000$ & Advantage & 1.03 \\
\hline IDR. 6100) & 1.23 & R/ C Ratio & \\
\hline Advantage & & & \\
\hline R/C Ratio & & & \\
\hline
\end{tabular}

In Table 4, the input costs incurred to produce soybean seeds are calculated in a period of one growing season. The cost structure of soybean farming is dominated by labor costs. The cost component of the use of labor reached $72.9 \%$ of the total cost. Of the total labor costs $46.7 \%$ are harvest and post-harvest costs. Cost of production facilities $27.0 \%$. Meanwhile, for the next final seeding process, the energy consumption component is much smaller, which is around $3.8 \%$, the cost of labeling and packaging is $4.2 \%$, while the cost of certification and testing is only $0.69 \%$. The biggest cost or $89.6 \%$ for seed purchase capital. In the use of labor the biggest cost components are planting, harvesting and threshing. The cost of threshing seeds is paid in kind (soybean) with a calculation of $8: 1$, meaning that the owner of the field share gets 8 and the harvester share gets 1 .

The results of the financial analysis of seed captive farming at the breeder level show that from the purchase of $1,000 \mathrm{~kg}$ of prospective seeds, a net profit of $\mathrm{Rp}$ 262,100 is obtained. The net profit of soybean seed breeding business in Southeast Sulawesi is Rp. $243 / \mathrm{kg}$. Although it has a small profit, this soybean captive farming is economically profitable with an $\mathrm{R} / \mathrm{C}$ ratio $>1$, which is 1.03 . 
c. Establishment of Inter-Field and Seasonal Inter-seasoning based on land potential The region of Southeast Sulawesi Province is mostly hilly (74\%), while the rest is flat to wavy (26\%) [22]. From environmental sustainability considerations, land use for soybean development, is only in areas with flat to undulating topography, $26 \%$ of the area of Southeast Sulawesi, or 991,640 ha. In particular, rice fields with an area of 92,542 ha, it was concluded that this province still has a great opportunity to increase soybean production through expanding the planting / harvesting area and increasing productivity by intensifying cultivation using the following assumptions: (a). Follow the recommended cropping pattern : (a). Irrigated rice fields: "Rice - Rice - Soybean", and (b) Rainfed: "Rice - Soybean - Bero". From these calculations, it can be seen that from the wetland area (irrigation and rainfed).

\section{Conclusion and recommendation}

The highest soybean production and productivity in Southeast Sulawesi Province occurred in 2016 , experiencing an increase of $21 \%$ even though the planting area decreased by $22 \%$ from 2015, but soybean seed production continued to decline from year to year. In 2016, Southeast Sulawesi's soybean seed production only met $73.5 \%$ of its needs. This indicates that the soybean seed production business in Southeast Sulawesi has the opportunity to be developed. The seeds at the farmer level are obtained from their own crops and government assistance / projects, the dominant variety that farmers are interested in is Anjasmoro. Analysis of the procurement of seeds at the breeder level shows that from purchasing 1,000 $\mathrm{kg}$ of prospective seeds, a net profit of IDR 262,100 with an R/C ratio of $>1$ is obtained, meaning that soybean seed farming in Southeast Sulawesi is economically profitable.

\section{References}

1. L.O.G. Halim, W.O.R. Ariani. Asian J. Crop Sci. 12, 2 (2020)

2. M. Assad, S. B. Sugiman. Jurnal Pengkajian dan Pengembangan Teknologi Pertanian 31, 37 (2018)

3. G.S. Budi, M. Aminah. Forum Agro Ekonomi 28, 1 (2010)

4. K. Zakaria, W. K. Sejati, R. Kustiari. Jurnal Agro Ekonomi 28, 1(2010)

5. M. Siregar. Forum of Agro-Economic Research 17, 1 (1999)

6. M. O. Adnyana. Identifikasi Dan Analisis Komoditas Tanaman Pangan Untuk Menciptakan Peluang Pasar. Bogor, Indonesia. (2006)

7. S. Bananiek, et al. "Analisis Kebijakan Perbenihan Kedelai Di Provinsi Sulawesi Tenggara." in Laporan Akhir Kegiatan. Sulawesi Tenggara, Indonesia: BPTP Sulawesi Tenggara. (2014)

8. IB. Suastika, I.K. Kariada. Prosiding Seminar Nasional Kedaulatan Pangan dan Energi. Fakultas Pertanian, Universitas Trunojoyo, Madura. (2012)

9. H. Bahari, L.O.G. Saediman, N. Arif. International Journal of Economics and Financial Issues 9, 6 (2019)

10. Statistics Indonesia [BPS], Jakarta, Indonesia (2018)

11. Soekartawi. Prinsip Dasar Ekonomi Pertanian Jakarta (UI Press, Jakarta, 2016)

12. Laporan Tahunan BPSB Provinsi Sulawesi Tenggara, Sulawesi Tenggara, Indonesia (2015)

13. Kementerian Pertanian. Statistik Pertanian Indonesia, Kementan RI, Jakarta, Indonesia (2015).

14. Kementerian Pertanian. Statistik Pertanian Indonesia, Kementan RI Jakarta. Indonesia. (2019) 
15. Sulawesi Tenggara Dalam Angka 2013 [BPS]. Sulawesi Tenggara, Indonesia (2013)

16. D. Harnowo, Subandi. Prosiding Simposium Tanaman Pangan Inovasi Teknologi Tanaman Pangan Buku 3:Penelitian dan Pengembangan Palawija. Pusat Penelitian dan Pengembangan Tanaman Pangan. Badan Penelitian dan Pengembangan Tanaman Pangan. Bogor, Indonesia.(2008)

17. Z. Abidin, D. Harnowo. Jurnal Pengkajian dan Pengembangan Teknologi Pertanian 13, 167 (2010)

18. Laporan Tahunan BPSB Provinsi Sulawesi Tenggara. Sulaweai Tenggar, Indonesia (2016)

19. Dinas Pertanian Provinsi Sulawesi Tenggara. Laporan Tahunan Dinas Pertanian dan Tanaman Pangan Provinsi Sulawesi Tenggara. (2016)

20. Heriyanto. Balai Penelitian Tanaman Kacang Kacangan dan Umbi-Umbian. (2012)

21. Balitkabi. Deskripsi Varietas Unggul Jakarta: Badan Litbang Pertanian. Jakarta, Indonesia (2016)

22. Z. Abidin. Jurnal Pengkajian dan PengembanganTeknologi Pertanian 14, 92 (2011) 